J. Clin. Chem. Clin. Biochem.

Vol. 18, 1980, pp. 403-406

\title{
Non-destructive Neutron Activation Analysis of Aluminium and Phosphorus in Bone Biopsies
}

\author{
By W. Gatschke, D. Gawlik
}

Hahn-Meitner-Institut für Kernforschung Berlin and

\section{Kraft}

\section{Klinikum Steglitz der Freien Universität Berlin}

(Received October 8, 1979/January 21, 1980)

Summary: The level of aluminium and phosphorus in bone was measured by neutron activation analysis via the short lived radionuclide ${ }^{28} \mathrm{Al}$. The contribution of both elements to the ${ }^{28} \mathrm{Al}$ activity could in each case by determined after the samples had been irradiated twice, once with a cadmium shield around the irradiation position.

The samples were analysed non-destructively and may later be used for further tests.

Limits for the quantitative determination of aluminium and phosphorus in usual bone biopsies were calculated.

\section{Zerstörungsfreie Neutronen-Aktivierungsanalyse von Aluminium und Phosphor in Knochenbiopsien}

Zusammenfassung: Der Gehalt von Aluminium und Phosphor in Knochen wurde mittels Neutronen-Aktivierungsanalyse über das kurzlebige Radionuklid ${ }^{28} \mathrm{Al}$ gemessen. Der jeweilige Beitrag der beiden Elemente zur ${ }^{28} \mathrm{Al}$-Aktivität konnte getrennt bestimmt werden nach zwei Bestrahlungen der Proben, davon eine Bestrahlung mit einem Cadmiumschirm über der Bestrahlungsposition. Die Proben wurden zerstörungsfrei analysiert und können danach für weitere Tests verwendet werden.

Es wurde die Bestimmungsgrenze für Aluminium und Phosphor in üblichen Knochenbiopsien berechnet.

\section{Introduction}

Following recent reports of drastic increases in aluminium levels in dialysis patients, interest has been generated in the analysis of this element in bone $(18,19)$. The usual small size biopsies are generally used for a variety of tests. The only method of analysis by which aluminium can be determined non-destructively in biological material is neutron activation analysis. It involves measurement of the radionuclide ${ }^{28} \mathrm{Al}$ which forms after an $(\mathrm{n}, \gamma)$ reaction. The fast neutrons in the reactor neutron spectrum are responsible, however, via an $(\mathrm{n}, \alpha)$-reaction for the production of the same radionuclide from ${ }^{31} \mathrm{P}$. The ratio of phosphorus to aluminium in bone is about 2500.

With a ratio of 0.1 for the fast to thermal neutron flux the ratio of the specific ${ }^{28} \mathrm{Al}$ activity originating from aluminium to that from phosphoris is 1400 . The phosphorus interference must therefore be taken into account The physiological silicon/aluminium ratio is such that the interfering reaction, ${ }^{28} \mathrm{Si}(\mathrm{n}, \mathrm{p}){ }^{28} \mathrm{Al}$, can be ignored. Phosphorus interference was not considered in the two papers so far published on the non-destructive determination of aluminium by neutron activation analysis $(1,2)$. Gilmore et al. (3) separated the aluminium before irradiation and determined it after irradiation on an ion exchanger. All other authors use either arc emission or flame emission spectrometry after the bones have been ashed (4-9).

The phosphorus level and the phosphorus/calcium ratio are of importance in the diagnosis of pathological states in bone. To date only Batra et al. (10) have reported on the determination of phosphorus in bone by neutron activation analysis.

The aim of this work was to test the suitability of neutron activation analysis for the simultaneous, nondestructive determination of aluminium and phosphorus in bone biopsies via the short-lived radionuclide ${ }^{28} \mathrm{Al}$. 


\section{Experimental}

The samples were irradiated in a pneumatic transport system which is installed in a beam tube in the reactor BER II. The irradiation position of this installation can be shielded by a movable cadmium shield.Highly pure polyethylene containers were used for the samples. The aluminium and phosphorus levels of the containers are below the detection limit of this method. These containers were transported in nylon capsules to and from the irradiation position and were automatically removed from them before measuring. In this way it was possible to prevent contamination of the sample containers by the material of the tube system (an aluminium alloy). Details concerning the measuring system can be found in l.c. $(11,12)$. The thermal neutron flux density at the irradiation position without cadmium shielding is $1.5 \times 10^{13} \mathrm{~cm}^{-2} \mathrm{~s}^{-1}$ and with shielding

$1.5 \times 10^{12} \mathrm{~cm}^{-2} \mathrm{~s}^{-1}$. The fast neutron flux is decreased by about $10 \%$ by the screening effect. Samples and standards were irradiated under these conditions for $20 \mathrm{~s}$ with and without cadmium shielding and, after waiting $30 \mathrm{~s}$ for the short lived activity to decay, they were measured for $200 \mathrm{~s}$ using a coaxial $\mathrm{Ge}(\mathrm{Li})$-detector. The upper limit of the irradiation time was set by the maximum integral counting rate workable in the system of measurement used. The $1778.80 \mathrm{keV} \gamma$-line of the ${ }^{28} \mathrm{Al}$ (half life $2.31 \mathrm{~m}$ ) was used to calculate the mass. Aqueous solutions of aluminium chloride and lithium phosphate served as standards. Details of the evaluation are described in 1.c. (13). In addition the aluminium content was determined by atomic absorption spectrometry. The samples were dissolved according to a procedure described by Singer \& Armstrong (20).

\section{Results}

A bone powder standard used in our laboratory was taken for the investigation of the analytical method with regard to sensitivity, detection limit and systematic errors. The preparation of the standard is described in 1.c. (14). Up to $20 \mu \mathrm{g}$ aluminium in the form of aluminium chloride and up to $20 \mathrm{mg}$ phosphorus in the form of lithium phosphate were added to about $100 \mathrm{mg}$ of the fresh non ashed standard and the phosphorus and aluminium content was determined in two series of experiments (constant phosphorus level with increasing aluminium level and constant aluminium level with increasing phosphorus level). The results of these measurements are given in figures 1 and 2 .

The aluminium content of the bone powder standard measured by atomic absorption spectrometry is $45 \pm 5 \mathrm{mg} \cdot \mathrm{kg}^{-1}$ (mean \pm s.d.).

In addition, the phosphorus and aluminium levels in bone samples of the crista iliaca (of 10 persons) were measured. The data are listed in table 1 .

\section{Discussion}

In order to test the analytical procedure for systematic errors and to determine its sensitivity the addition method seemed most suitable. As both elements (phosphorus and aluminium) are detected via the same radionuclide ${ }^{28} \mathrm{Al}$, it was above all of importance to investigate the effect of different amounts of the one element

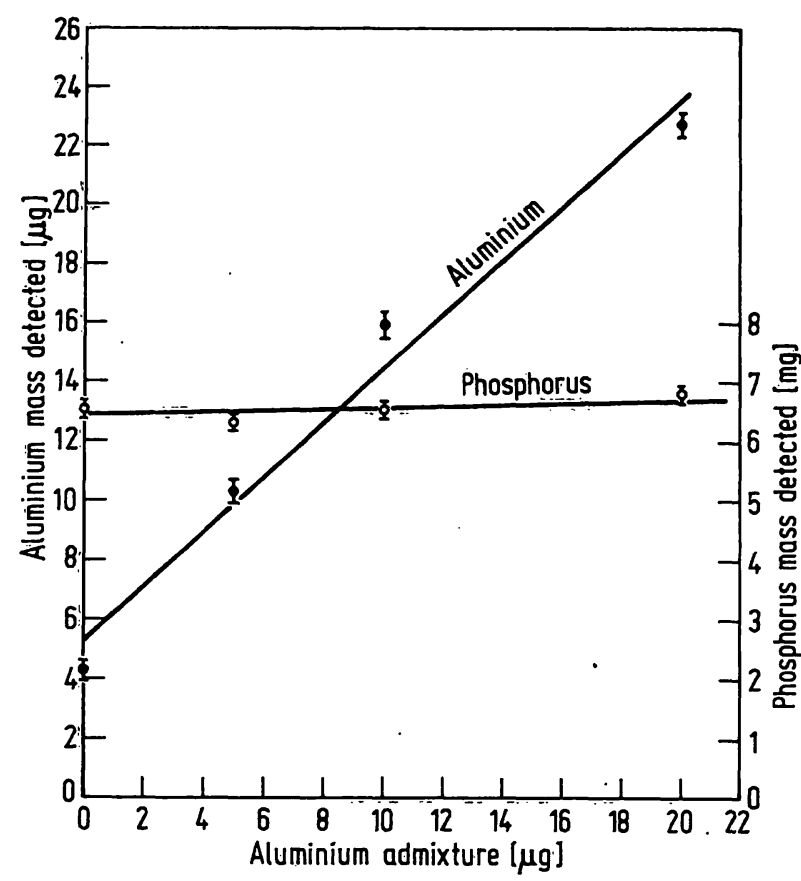

Fig. 1. Aluminium and phosphorus content measured in $94.3 \mathrm{mg}$ bone powder standard (fresh) after different amounts of aluminium had been added. The bars indicate the standard deviation from the counting statistics only.

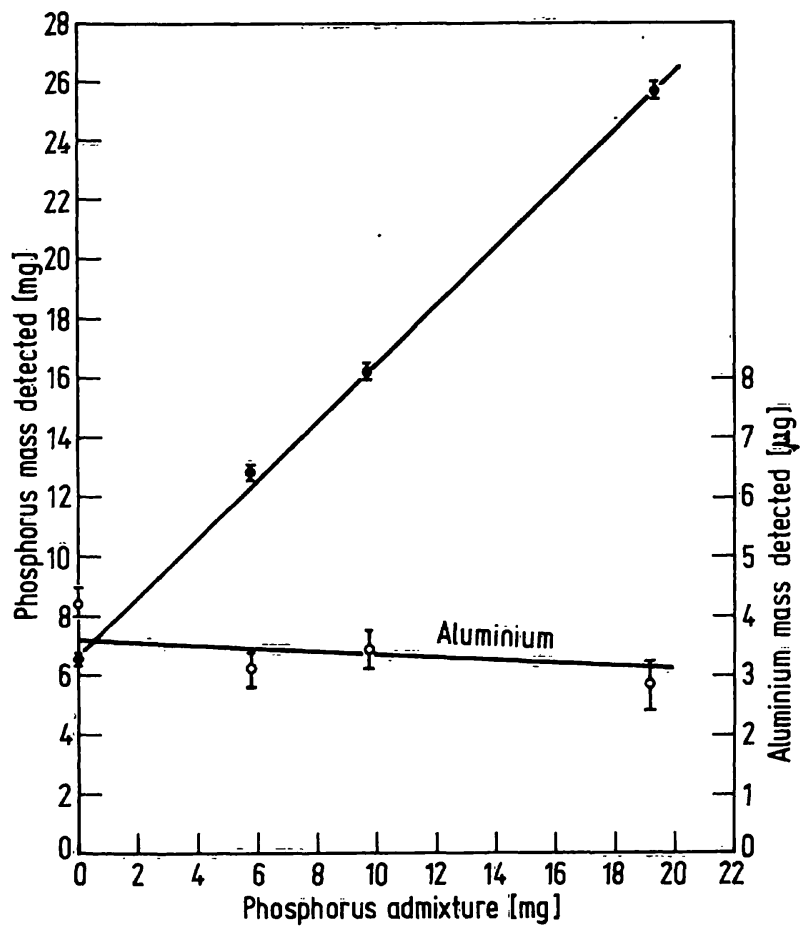

Fig. 2. Aluminium and phosphorus content measured in $94.3 \mathrm{mg}$ bone powder standard (fresh) after different amounts of phosphorus had been added. The bars indicate the standard deviation from the counting statistics only.

on the detected amount of the other. The bone powder standard was an appropriate matrix since its aluminium and phosphoruis contents lie within the order of magnitude of the physiological levels from human bone biopsies. 
Tab. 1. Aluminium and Phosphorus content in bone samples (defatted, dry) of the crista iliaca (trabecular bone only) originating from 10 persons. Samples taken at the department of pathology at the Klinikum Steglitz, Freie Universität Berlin*).

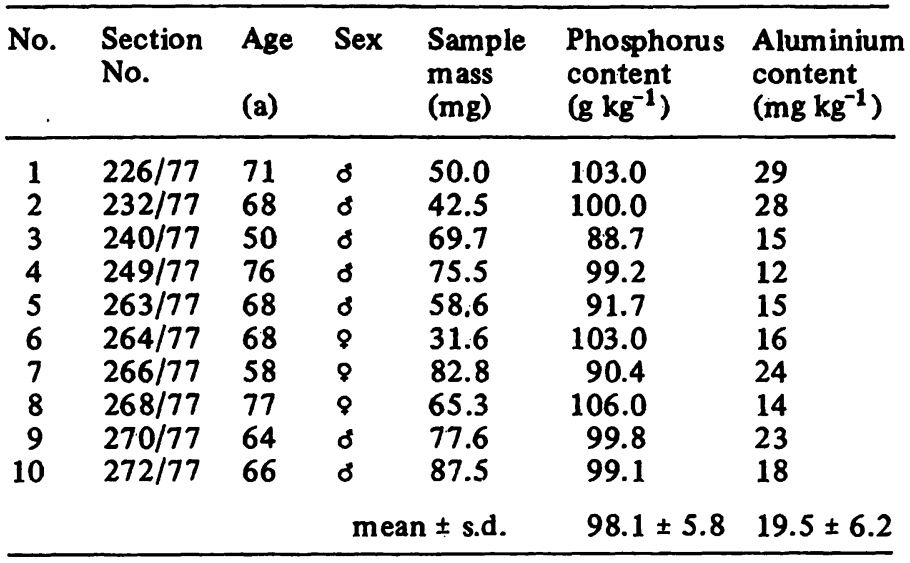

*) We are indebted to Prof. Gross of the department of pathology, Klinikum Steglitz, FU Berlin, for providing us with the bone samples.

The linear regression after addition of phosphorus (fig. 1) showed $\mathrm{m}_{\mathrm{P} \text { mass detected }}=6.71+0.992 \mathrm{~m}_{\mathrm{P} \text { added }}$ with $\mathrm{r}^{2}=0.9991$.

The range of the phosphorus content is 6.5 to $25.7 \mathrm{mg}$ (6.9 to $27.3 \%$ ). The calculated sensitivity in this range is $450 \mathrm{mg}^{-1}$. The amounts of aluminium determined with the varying phosphorus levels ranged from 2.9 to $4.3 \mu \mathrm{g}$. The far greater standard deviation of the measured aluminium levels was due to the fact that, with the phosphorus/aluminium ratios used in this case (between about 1700 and 6500), the majority of the ${ }^{28} \mathrm{Al}$ activity was produced from the phosphorus.

Similary the linear regression after addition of aluminium (fig. 2) showed $\mathrm{m}_{\mathrm{Al} \text { mass detect. }}=\mathbf{5 . 3 1}$ $+0.913 \mathrm{~m}_{\mathrm{Al}}$ added with $\mathrm{r}^{2}=0.978$ and a calculated sensitivity of $456 \mathrm{\mu g}^{-1}$ within the range of the aluminium content from 4.3 to $22.8 \mu \mathrm{g}$ ( 45 to $241 \mathrm{mg} \mathrm{kg}^{-1}$ ). The amounts of phosphorus determined with the varying aluminium levels were between 6.3 and $6.9 \mathrm{mg}$.

The aluminium content of the pure bone powder standard as determined by this method corresponds with the value obtained by atomic absorption spectrometry.

\section{References}

1. Mc Kown, D., Kay, M., Gray, D., Abu-Samra, A., Eichor, M. \& Vogt, J. (1950), Nucl. Meth. in Environ. Res. (Columbia), $150-157$.

2. Goode, G. C., Howard, C. M., Wilson, A. R. \& Parsons, V. (1972), Anal. Chim. Acta 58, 363-368.

3. Gilmore, G. R. \& Goodwin, B. L. (1972), Radiochem. Radioanal. Letters 10, 217-222.
It can therefore be concluded that the method is free of systematic errors and that in the concentration ranges investigated phosphorus and aluminium can be determined independently via the same radiunuclide ${ }^{28} \mathrm{Al}$.

The usual type of bone biopsy sample is about $50 \mathrm{mg}$ (defatted, dry). It was necessary to find out whether physiological levels of phosphorus and aluminium can be determined in such biopsies.

Whereas the physiological level of phosphorus in defatted, dry bone is quoted repeatedly in the literature as about 7 to $12 \%$ (dependent on the age) (15), widely varying values, between 2.4 and $6540 \mathrm{mg} \mathrm{kg}^{-1}$, can be found for the aluminium content. In the most comprehensive work Nusbaum et al. (4) quote a value of $30 \mathrm{mg} \mathrm{kg}^{-1}$, whereas 57 to $67 \mathrm{mg} \cdot \mathrm{kg}^{-1}$ are mertioned in more recent publications.

The levels which we measured in 10 persons (between 12 and $29 \mathrm{mg} \cdot \mathrm{kg}^{-1}$ aluminium and between 8.9 and $10.6 \%$ phosphorus) in trabecular bone samples of the iliac crest therefore correspond more or less to the literature values. They represent a mean value of $19.5 \pm 6.2 \mathrm{mg} \mathrm{kg}^{-1}$ for aluminium and $9.81 \pm 0.58 \%$ for Fhosphorus (mean \pm s.d.) (tab. 1).

For the estimation of a normal value for the aluminium content in bone a detailed investigation will be necessary on a greater number of individuals. Such an investigation must take in to account the influence of nutrition (e.g. the application of aluminium-containing antacids which is quite common today) and the distribution of aluminium within the skeleton (e.g. the different content of aluminium in trabecular and cortical bone).

The limit of quantitative determination (standard deviation $10 \%)$ in a $50 \mathrm{mg}$ biopsy is $0.5 \mu \mathrm{g}\left(10 \mathrm{mg} \mathrm{kg}^{-1}\right)$ for aluminium and $0.6 \mathrm{mg}(1.2 \%)$ for phosphorus. It is therefore possible to measure non-destructively the level of aluminium and phosphorus in bone biopsies.

As has already been described $(16,17)$, the physiological levels of fluorine, calcium, sodium and chlorine in bone biopsies can also be measured non-destructively with the same equipment after an irradiation time of $20 \mathrm{~s}$. This analytical method therefore allows these 6 import elements to be tested simultaneously. Five minutes are required for one analysis including data evaluation.
4. Nusbaum, R. E., Butt, E. M., Gilmour, T. C. \& Didio, S. L. (1965), Arch. Environ. Health 10, 227-235.

5. Kehoe, R. A., Cholak, J. \& Story, R. V. (1940), J. Nutr. 19, 579-592.

6. Sparado, J. A., Becker, R. O. \& Bachmann, C. H. (1970), Calcif. Tissue Res. 6, 49-54. 
7. Hamilton, E. I., Minski, M. J. \& Cleary, J. J. (1972), Sći. Total Environ. 1, 341-374.

8. Stitch, S. R. (1957), Biochem. J. 67, 97-103.

9. Eastoe, J. E. in Biochemists Handbook, E. and F. N. Spon Ltd. (London 1968), 715-720.

10. Batra, G. J. \& Bewley, D. K. (1973), J. Radioanal. Chem. $16,275-280$.

11. Brätter, P., Gatschke, W., Gawlik, D., Möllèr, J. \& Wenckel, W. (1976), Report HMI-B 188.

12. Brätter, P., Gatschke, W., Gawlik, D. \& Klatt, S. (1977), Kerntechnik 19, 255-227.

13. Gatschke, W. \& Gawlik, D. submitted for publication in J. Radioanal. Chem.
14. Lausch, J. (1977), Diss. FU Berlin.

15. Documenta Geigy, Wissenschaftliche Tabellen (1975), 517.

16. Behre, D., Brằtter, P., Gawlik, D., Keller, C., Möller, J.

\& Rösick, U. (1976), Medizinische Physik Vol. 2, 239-252.

17. Brätter, P., Gälik, D., Jost, P., Möller, J. \& Reimers, P. (1977), Z. Anal. Chem. 283, 121-127.

18. Flendrig, J. A., Kruis, H. A. \& Das, H. A. (1976), Proc. Eur. Dial. Transplantn. Ass. 13, 355-361.

19. Alfrey, A. C., Hegg, A., Miller, N.; Berl, T. \& Berns, A. (1979), Mineral Electroly te Metabolism 2, 81-87.

20. Singer, L. \& Armstrong, W. D. (1968), Anal. Chem. $40,613-614$.

Dr. Dieter Gawlik

Hahn-Meitner-Institut für Kernforschung Berlin Glienicker Str. 100

D̈-1000 Berlin 39 